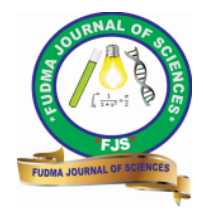

FUDMA Journal of Sciences (FJS)

ISSN online: $2616-1370$

ISSN print: 2645 - 2944

Vol. 4 No. 3, September, 2020, pp $242-246$

DOI: https://doi.org/10.33003/fjs-2020-0403-407

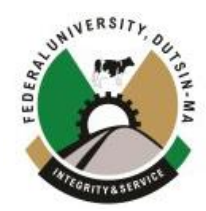

\title{
ASSESSMENT OF RADON CONCENTRATION AND ASSOCIATED HEALTH IMPLICATIONS IN GROUND WATER AND SOIL AROUND RIRUWAI MINE SITE, KANO STATE, NIGERIA AND ITS ENVIRONS.
}

\author{
Umma Abdullahi, A. Asuku, A. Umar, Y. A. Ahmed, U. S. Adam, N. F. Abdulmalik, M. H. Yunusa, and A. R. Abubakar \\ Centre for Energy Research and Training (Nigeria Atomic Energy Commission), Ahmadu Bello University, Zaria, \\ Kaduna State, Nigeria \\ Corresponding Author's email: asukuabdulsamadyisa@yahoo.com
}

\begin{abstract}
In this study 10 soil and 11 ground water samples were randomly collected, and the ${ }^{222} \mathrm{Rn}$ concentrations were measured using a DURRIDGE RAD7 electronic radon detector. The radon concentration in ground water ranged from $0.53 \mathrm{BqL}^{-1}$ to $5.13 \mathrm{BqL}^{-1}$ with a mean value $2.37 \mathrm{BqL}^{-1}$. The results show that all the groundwater samples collected have ${ }^{222} \mathrm{Rn}$ concentrations below the US EPA Maximum Contaminant Level (MCL) of $11.1 \mathrm{BqL}^{-1}$ (for states without radon monitoring policy and enhanced indoor air programs). All the ground water samples also have ${ }^{222} \mathrm{Rn}$ concentrations below MCL of $100 \mathrm{BqL}^{-1}$ recommended by EU. The annual effective dose due to ingestion $\left(H_{\text {ing }}\right)$ of ${ }^{222} \mathrm{Rn}$ in the groundwater ranged from $0.00386-0.03744$ $\mathrm{mSvyear}^{-1}$ with a mean value of $0.01706 \mathrm{mSvyear}^{-1}$. These values are within the ICRP recommended reference level of $1 \mathrm{mSvy}^{-1}$ for the intake of the radionuclide in water by the general public for a prolonged exposure. The effective radium content, radon mass exhalation rate and alpha index of the soil samples varied from $0.574-1.170 \mathrm{Bqkg}^{-1}, 0.104 \mathrm{Bqkg}^{-1} \mathrm{~d}^{-1}-0,212 \mathrm{Bqkg}^{-1} \mathrm{~d}^{-1}$ and $0.00287-0.00585$ respectively. The alpha index suggests that none of the selected soil samples have a radon mass exhalation that could cause indoor radon concentrations exceeding $200 \mathrm{Bqkg}^{-1}$. Therefore, it is concluded that the radon concentration in ground water and soil in the study area indicate that the ground water is safe for drinking and it is safe to use the soil as a building material.
\end{abstract}

Keywords: Radon, Ground water, Soil, Exhalation Rate, Annual Effective Dose.

\section{INTRODUCTION}

Radon gas is the major contributor of ionizing radiation to human. It is a naturally occurring radioactive gas with no smell, colour or taste. Radon is produced from the natural radioactive decay of uranium, which is found in all rocks and soil (Oni et al, 2016; Sudhir, 2016). Radon can also be found in water (WHO, 2016). It is an element with atomic number of 86 and its mass number varies from 200 to 222 . Radon gas (Rn222 ) is formed when Radium-226 with half-life equal to 1600 years disintegrates according to Uranium-238 decay series (Shakir Khan et al, 2012; Huda et al, 2012; Deepak, 2012).

The presence of natural radioactivity and radon exhalation in soil and water contribute to the radiation dose received by human. Arabi et al (2017) carried out an assessment of the ${ }^{222} \mathrm{Rn}$ concentration in ground water samples from Mika Uranium mineralization and its environ. It was found that $76.5 \%$ of the groundwater samples collected had ${ }^{222} \mathrm{Rn}$ concentrations far above the US EPA maximum contaminant level (MCL) of $11.1 \mathrm{BqL}^{-1}$ (for states without radon monitoring policy and enhanced indoor air programs), and only $23.5 \%$ have lower values. However, all the ${ }^{222} \mathrm{Rn}$ levels were below the MCL of $100 \mathrm{BqL}^{-1}$, recommended by European Union (EU). The magnitude of the annual effective dose due to ingestion ( $\left.H_{\text {ing }}\right)$ of ${ }^{222} \mathrm{Rn}$ in the groundwater samples were found to be within the International Commission on Radiological Protection (ICRP) recommended reference level of $1 \mathrm{mSvyear}^{-1}$ for the intake of the radionuclide in water by the general public for a prolonged exposure. Similar study was performed by Oni et al (2016) in Ado-Ekiti, Nigeria, where the ${ }^{222} \mathrm{Rn}$ concentration in some of the ground water samples were found to have values above the MCL of $11.1 \mathrm{BqL}^{-1}$, recommended by US EPA. Radon exhalation rate was determined in some selected Building materials by Asuku et al (2019) using closed chamber technique. The result indicated that, Radium and Radon contents from selected building materials were below the approved safety limit hence they pose no radiation risk. Radionuclides and radon levels in soil and ground water from solid minerals-hosted area, Southwestern Nigeria was also assessed by Felix et al (2016). The authors recommended that public water system should be revisited by relevant government agencies and efforts should be made to educate the public on the effects of radon.

Riruwai, located in Doguwa Local Government Area of Kano State, is a mining community where mechanized mining once flourished there (Muhammad, 2017). It was also estimated that over 200 million tons of rock containing over 0.5 million tons of Niobium and Uranium ore could be found in Riruwai (Untapped Resources of Kano State 2001). Currently there are reports of illegal mining occurring around Riruwai mine site and its environs. The People around Riruwai mine site and its environs use soil for building/construction and water for drinking. It is essential to ascertain the level of Radon concentration presence in both soil and water because, in such areas, the illegal miners and mining communities are at risk of negative health issues like, lung cancer and occurrence of respiratory dysfunctions which are mostly caused by inhalation of large amount of Radon. Consequently, this work reports an assessment of Radon Concentration and associated Health implications in groundwater and soil around Riruwai mine site, Kano state, Nigeria and its environs. 


\section{MATERIALS AND METHODS}

\section{Materials}

The materials used for this work include soil and ground water samples randomly collected from different locations around Riruwai mine as listed in Table 1. Other materials include bailers, jars, polythene bags, mortar and pestle, sieve, plastic containers, and the DURRIDGE RAD7 (MA 01821/3332), an electronic radon detector.

\section{METHODOLOGY}

\section{Study area}

The study area, Riruwai, is a mining community with a population of about 151,181 people according 2006 census, located in Doguwa Local Government Area of Kano State. It is bounded by latitude 10042'13 - 10045'00"N and longitude $8045^{\prime} 00 "$ - 8047'39" E covering an area of $109 \mathrm{~km}^{2}$. (Muhammad, 2017).

\section{Sample Preparation}

A total of eleven (11) ground water samples from wells and streams were carefully collected into dry, clean jars and covered to avoid contamination and escape of radon, since radon is a radioactive gas. Bailers were used to collect the well samples while clean jars were carefully dipped into the stream to collect the stream samples. The jars were filled to the brim to prevent the formation of air pockets.

Ten (10) soil samples were collected in clean, dry polyethylene bags from around the same location where the water samples were collected. The soil samples were collected from $30 \mathrm{~cm}$ hole dug into the ground in each location so as to get the natural soil. After collection, the soil samples were crushed into fine powder using a mortar and pestle to allow for maximum exhalation. In order to ensure a fine quality of the sample, a sieve was used. The soil samples were dried in an oven at about $80^{\circ} \mathrm{C}$ for $24 \mathrm{hrs}$. Each sample was packed, sealed and kept for about a month in an airtight plastic container so as to ensure secular equilibrium between radium and radon progenies of both uranium and thorium series. The mass of the soil samples was $200 \mathrm{~g}$. All samples were marked and carefully labelled to reflect both the time and location of collection so as to ensure easy identification and prevent interchange of sample results during analysis. The soil and water samples were later transported to the laboratory for analysis.

\section{Sample analysis}

In analyzing the samples, the RAD7 electronic radon detector supplied by DURRIGDE Company, USA was used. DURRIDGE is responsible for the calibration of all instruments to a set of four "master" instruments with a calibration precision of about $1 \%$. The master instruments have been calibrated by way of inter-comparison with secondary standard radon chambers designed by the U.S. EPA. The accuracy of the master instrument was estimated to be within $4 \%$, based on inter-comparison results. The overall calibration accuracy of our RAD7 was estimated to be better than 5\%.

The RAD- $\mathrm{H}_{2} \mathrm{O}$ closed loop aeration method was employed (AlZabadi et al, 2012) to measure the radon activity concentration in the water samples. The RAD AQUA continuous water measurement accessory was used so as to measure radon activity concentration in water to extremely low concentrations, a process which ensures that the air volume and water volume are constant and independent of the flow rate. The process involves continuous extraction of the radon as air circulates through the water until a state of equilibrium is reached. This state of equilibrium is reached in about 5 minutes, after which no more radon can be extracted from the water. The results of the measurement are shown on the RAD-7 screen after 30 minutes with an accuracy and sensitivity that exceeds that of other existing devices (Durridge, 2016; Oni, 2019).

The accumulator chamber method was used in carrying measurements of radon activity concentration for soil samples (Tuccimei et al. 2006; Bruzzi and Righi 2006). In this method, each of selected samples was placed one after the other inside a container called "accumulator chamber" in order to allow radon concentration to build up inside the chamber. This was done for 24 hours (one day). The accumulator chamber was then attached to the RAD-7 by two tubes, one to the inlet on the detector through a desiccant, which was also necessary during measurement in order to absorb all the moisture that would otherwise affect the radon concentration in the soil samples. The detector achieves this by detecting alpha particles emitted by the Radon and its progenies from the sample.

\section{Radiological Hazards Parameters \\ Radon activity concentration}

An increased risk of developing lung cancer, which depends on the radon concentration and the length of exposure, is the major health risk associated with long term, elevated exposure to radon. The equation that relates the buildup of radon activity concentration and the effective radium content of each sample is given by equation (1); (Abo-Elmagd et al, 2018; Rafat, 2015).

$$
C_{R n}(t)=C_{e q}\left(1-e^{-\lambda_{R n} t}\right)
$$

Where

$\mathrm{C}_{\mathrm{Rn}}$ is the radon activity concentration at a time $\mathrm{t}$.

$\mathrm{C}_{\text {eq }}$ is the equilibrium radon concentration

$\lambda_{R n}$ is the decay constant of Radon

$\mathrm{t}$ is the time taken to build Radon activity inside a tight exhalation container.

\section{Annual effective dose due to ingestion}

An assessment of annual effective dose due to ingestion was performed based on the intake of water by the general public around Riruwai and its environs. The estimation of the annual effective dose due to ingestion was done using Eq. (2) (Oni et al, 2019). It was assumed that a conservative consumption, for standard adult drinking the same water and directly from the source, for dose estimation is 2 litres per day (Oni et al, 2019).

$E=K \times C \times K M \times t$

Where:

$E==$ committed effective dose from ingestion;

$K=$ ingesting dose conversion factor of radon $\left(10^{-8} \mathrm{SvBq}\right.$ for adult) (UNSEAR, 1993)

$C=$ radon concentration

$K M=$ average water consumption per day (2 litre /day)

$t=$ duration of consumption (365 days) (WHO, 2006)

Effective radium content and Radon mass exhalation rate

The effective radium content and the exhalation rates are two 
major indicators of radon risk among others. The magnitude of the exhalation rate is usually quantified in terms of surface exhalation rate or mass exhalation rate, which is defined as the number of radon atoms leaving a unit surface area or mass of the material per unit time. Soil sample having the same ${ }^{226} \mathrm{Ra}$ activity levels may have varying radon exhalation rate. Consequently, it is not possible to determine the radon exhalation rate of soil samples simply from the activity concentration of ${ }^{226} \mathrm{Ra}$ (Jing et al., 2010). The effective radium content $\left(R a_{e f f}\right)$ and radon mass exhalation rate $\left(E_{m}\right)$ of the soil samples in this study is given by equations (3) and (4) respectively; (EC, 1999, Abu-Elmagd, 2018):

$$
\begin{aligned}
& R a_{e f f}=\frac{C_{e q} V_{e f f}}{M} \\
& E_{m}=\frac{C_{e q} \lambda_{R n} V_{e f f}}{M}
\end{aligned}
$$

Where $M$ is the mass $(\mathrm{kg})$ of the soil samples, $V_{\text {eff }}\left(\mathrm{m}^{3}\right)$ is the effective volume of the chamber, $\lambda_{R n}$ is the decay constant of Radon, $\mathrm{C}_{\text {eq }}$ is the equivalent radon activity concentration at a time t.

Radon is an alpha emitter. This implication of this is that high radon inhalation has the possibility of causing an elevated alpha radiation in the internal organs of the body. Alpha index $\left(I_{\text {alpha }}\right)$, which is one of the several indexes used to assess radiation risk due to the radon inhalation originating from the soil and its related derivatives, is given by Equation (5) (Nisha et al, 2014; Rafat, 2015):

$I_{\text {alpha }}=\frac{C_{R a}}{200}$.

Where $C_{R a}$ is the radium activity concentration.

\section{RESULT AND DISCUSSION}

The result of the radon activity concentration and annual effective dose due to ingestion in water samples is presented in Table 1 . The radon activity concentration in the water samples ranged from $0.53-5.13 \mathrm{BqL}^{-1}$ with a mean value of $2.37 \mathrm{BqL}^{-(3)}$ ${ }^{1}$. The highest radon activity concentration was obtained in Rijiyar Kakume, while the lowest radon activity concentration was found to be in Green water as can be seen in Table 1. The mean value of radon activity concentration of $2.37 \mathrm{BqL}^{-1}$ in water from the

Table 1: Radon Concentration and Annual Effective Dose Due to Ingestion in Ground Water Sample I.D $\quad$ Radon Conc. $(\mathrm{Bq} / \mathrm{L}) \quad$ Annual effective dose

\begin{tabular}{ccc} 
& & $\begin{array}{c}\text { due to ingestion }\left(H_{\text {ing }}\right) \\
\times \mathbf{1 0}^{\mathbf{- 3}}\left(\mathrm{mSvyear}^{-1}\right)\end{array}$ \\
\hline Sarallinka & 1.21 & 8.83 \\
Dam & 0.97 & 7.08 \\
Rijiyar Kakume 2 & 2.24 & 11.64 \\
Rijiyar Kakume 1 & 5.13 & 37.44 \\
Rijiyar Sabo Layi 1 & 4.96 & 36.20 \\
Green Water & 0.53 & 3.86 \\
Rafin Kalwa & 0.66 & 4.81 \\
Rijiyar Unuguwar Kanawa & 4.04 & 29.49 \\
Rafin Laka & 1.57 & 11.46 \\
Rijiyar Wilbi & 1.80 & 13.14 \\
Rijiyar Sabon Layi 2 & 3.25 & 23.72 \\
\hline MEAN & 2.37 & 17.06
\end{tabular}

study area reveals that the radon activity concentration is low as compared to the Maximum Contaminant Level (MCL) of United States Environmental and Protection Agency (USEPA) which is $11.1 \mathrm{BqL}^{-1}$. This comparison is shown in Figure 1 . Additional comparison of the mean radon activity concentration in the study area with the standard value of 100 $\mathrm{BqL}^{-1}$ as recommended by European Commission (EC) also indicates that the radon activity concentration in all the samples were below the recommended limit. From our result, the radon concentration in all the samples compares well with similar study by Oni et al (2019), Arabi et al (2017) and Felix et al (2016) within Ogbomoso in Oya state, around Mika uranium mineralization and its environs in Taraba state and from solid minerals-hosted area, South Western, Nigeria, where the radon concentrations varied from $0.60-2.64 \mathrm{BqL}^{-1}, 2.350-46.20$ $\mathrm{BqL}^{-1}, 0.152-69600 \mathrm{BqL}^{-1}$ respectively. The low magnitude of radon concentration in our study could be attributed to the lithological units and depths at which the aquifers of the ground water are located. The annual effective dose due to ingestion ranged from $0.00386-0.03744$ mSvyear $^{-1}$ with a mean value of 0.01706 mSvyear $^{-1}$ as presented in Table 1 . These values are far below the International Commission on Radiation Protection (ICRP) recommended limit of 1 mSvyear ${ }^{-}$ ${ }^{1}$ for the ingestion of the radionuclide in drinking water by the general public for a prolonged exposure as shown in Figure 2. The effective Radium content, Radon mass exhalation rate and alpha index of the soil samples are presented in Table 2. The effective radium content ranges from $0.574 \mathrm{Bqkg}^{-1}-1.170$ $\mathrm{Bqkg}^{-1}$ while the radon mass exhalation rate ranges from 0.104 $\mathrm{Bqkg}^{-1} \mathrm{~d}^{-1}-0.212 \mathrm{Bqkg}^{-1} \mathrm{~d}^{-1}$. The radon mass exhalation rate obtained in our study is comparable with the reported values for some building materials in Zaria, Nigeria (Asuku et al, 2017; Arabi et al, 2015). The alpha index ranges from 0.00287 -0.00585 . Since none of the samples recorded an alpha index equal or greater than 1 , it implies that none of the soil samples have equivalent radium content that is equal to or greater than $200 \mathrm{Bqkg}^{-1}$ recommended limit by EC (1999). 


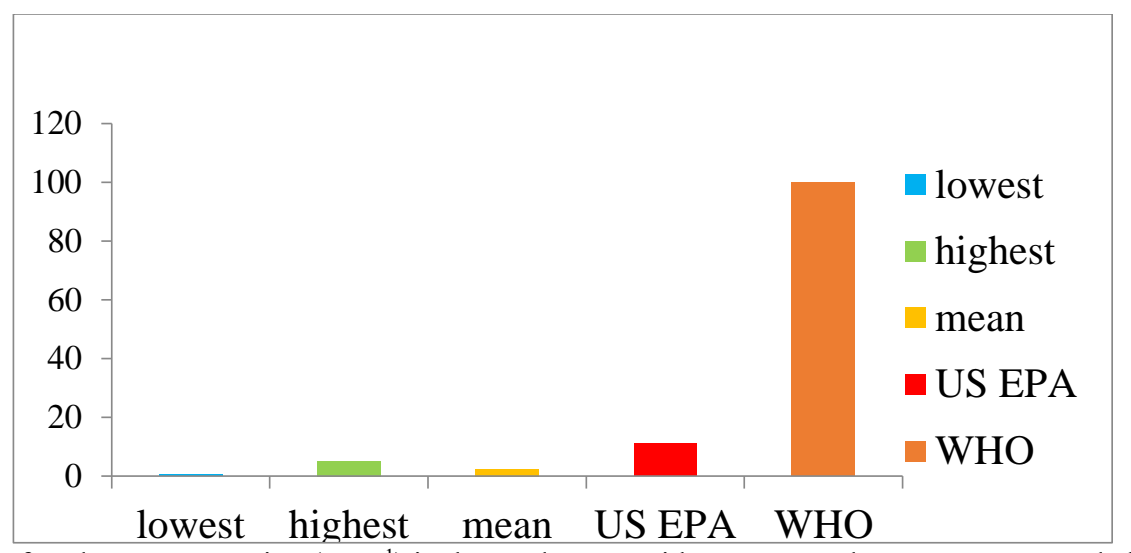

Fig. 1: Comparison of Radon Concentration $\left(\mathrm{BqL}^{-1}\right)$ in the Study Area with US EPA and WHO Recommended Limit.

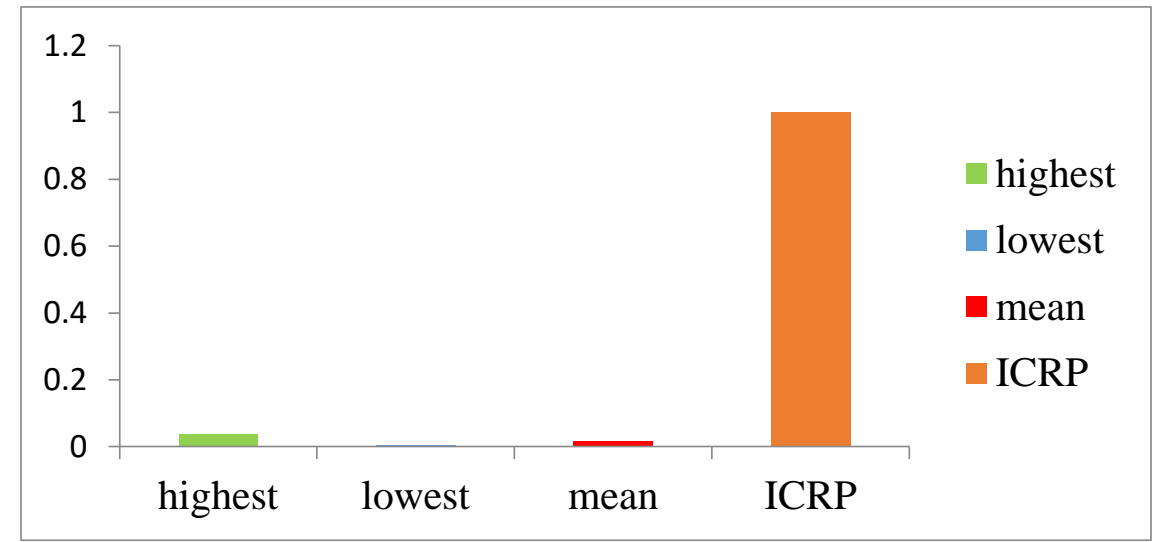

Fig. 2: Comparison of Annual Effective Dose Due to Ingestion $\left(\mathrm{mSvyear}^{-1}\right)$ in the Study Area with ICRP Recommended Limit.

Table 2: Effective Radium Content and Radon Mass Exhalation Rate in Soil

\begin{tabular}{ccccc}
\hline Sample I.D & Radon Conc & $E_{m}\left(\mathrm{Bqkg}^{-1} \mathrm{~d}^{-1}\right)$ & $R a_{\text {eq }}\left(\mathrm{Bqkg}^{-1}\right)$ & $\boldsymbol{I}_{\boldsymbol{a l p h a}}$ \\
\hline Sarallinka & 197 & 0.104 & 0.574 & 0.00287 \\
Dam & 361 & 0.190 & 1.049 & 0.005245 \\
Rijiyar Kakume2 & 336 & 0.177 & 0.977 & 0.004885 \\
Green Water & 358 & 0.188 & 1.038 & 0.00519 \\
Rijiyar Kakume1 & 304 & 0.160 & 0.883 & 0.004415 \\
Rijiyar Sabo Layi 1 & 269 & 0.141 & 0.778 & 0.00389 \\
Rafin Kalawa & 261 & 0.137 & 0.756 & 0.00378 \\
Rijiyar Unguwar Kanawa & 235 & 0.123 & 0.678 & 0.00339 \\
Rafin Laka & 284 & 0.149 & 0.822 & 0.00411 \\
Rijiyar Klilbi & 403 & 0.212 & 1.170 & 0.00585 \\
\hline
\end{tabular}

\section{CONCLUSION}

In this work, the radon concentration in ground water and soil around Riruwai Mine Site, Kano State, Nigeria and its environs was assessed using an electronic Radon detector (RAD7). The mean radon activity concentration and annual effective dose due to ingestion of $2.37 \mathrm{BqL}^{-1}$ and $0.01706 \mathrm{mSvyear}^{-1}$ in the ground water samples were found to be below WHO and ICRP recommended limits respectively. The ranges of the effective radium content, radon mass exhalation rate and alpha index in the soil samples was found to be $0.574 \mathrm{Bqkg}^{-1}-1.170 \mathrm{Bqkg}^{-1}$, $0.104 \mathrm{Bqkg}^{-1} \mathrm{~d}^{-1}-0.212 \mathrm{Bqkg}^{-1} \mathrm{~d}^{-1}$ and $0.00287-0.00585$ respectively. The magnitude of the alpha index suggests that none of the soil samples have an effective radium content equal to or greater than the $200 \mathrm{Bqkg}^{-1}$ recommended limit by EC. 
Consequently, in terms of radon concentration, the ground water from the study area is safe for drinking and it is safe to use the soil from the study area as a building material.

\section{REFERENCES}

Abo-Elmagd M. Ahmed Saleh, Afifi G. (2018). 'Evaluation of radon related parameters in environmental samples from Jazan city, Saudi Arabia', Journal of Radiation Research and Applied Sciences 11 (2018) 104-110

Asuku, A., Bello, I. A., Njidda, P. A. \& Umar, A. (2019). Determination of radon exhalation rate from some selected building materials in Samaru, Zaria-Nigeria, FUDMA Journal of Sciences, Vol. 3 No. 1, pp1-5.

Arabi .A.S, Funtua I.I, B. B. M. Dewu, and Muhammad A. M. (2015), 'Radiochemistry Background Radiation and Radiological Hazard Associated with Local Building Materials around Zaria, Nigeria' Radiochemistry Vol. 57, No. 2, pp. 207 212 .

Bruzzi L. Righi S., (2006) Natural radioactivity and radon exhalation in building materials used in Italian dwellings. J Environ Radioact 88:158-170

Deepak Verma, M. Shakir Khan and Mohd. Zubair (2012). Assessment of effective Radium content and Radon exhalation rates in soil samples, journal of Radioanal Nuclear Chemistry, DOI: $10.1007 / \mathrm{s} 10967-012-1694-1$

Durridge Radon Instrumentation RAD-H2O User Manual (2016). Available online at: https://www.durridge.com/documentation/ $\mathrm{rad} \% 20 \mathrm{H} 2020 \%$ man ual.pdf.

European Commission (EC), Radiation Protection Unit. (1999). Radiological protectionprinciples concerning the natural radioactivity of building materials. Radiation

Protection, 112. Ghosh, D., Deb, A., Bera, S., Sengupta, R., \& Patra, K. K.(2008).

Fasae K.P (2013) 'Natural Radioactivity in Locally Produced Building Materials in Ekiti State, Southwestern Nigeria' Civil and Environmental Research Vol.3, No.11, pp. 99 - 112.

Huda R. Algaim, Rifat M. Dakhil and Isa J. Al-Khalifa (2012). Determination of Radon and Thoron Activity in the Soil By using Solid State Nuclear Track Detectors (SSNTDs), Passive Technique, Advances in Applied Science Research, 3(2): 950961.

ICRP 'Protection Against Radon-222 at Home and at Work', ICRP Publication 65, Ann. ICRP, 1993, vol. 23, no. 2.
Muhammad Attahiru Abdullahi (2017). Assessment of Radiological Hazards around Ririwai Tin Mines, Kano State, North Western Nigeria, a PhD. thesis in Nuclear Physics, Department of Physics Faculty of Physical Sciences Ahmadu Bello University, Zaria.

Nisha Mann, Sushil Kumar, Amit Kumar, R.P. Chauhan and A.K. Garg (2014). Measurement of Radon Exhalation Rates in Soil Samples from Western Haryana, Journal of Applied Physics, 5(2): 56-59.

Oni, E.A., Oni, O.M., Oladapo O.O., Olatunde I.D., and Adediwura F.E. (2016). 'Measurement of Radon Concentration in Drinking Water of Ado-Ekiti, Nigeria' Journal of Academia and Industrial Research, Vol. 4 No. 8, pp19-23.

Oni Emmanuel Abiodun and Theophilus Aanuoluwa Adagunodo (2019). 'Assessment of Radon Concentration in Groundwater within Ogbomoso, SW Nigeria' J. Phys.: Conf. Ser. 12990120982019.

WHO 'Guidelines for Drinking Water Quality', Incorporating First Addendum, vol. 1 Recommendations, WHO, 2016, 3rd ed.

Rafat M. Amin (2015) 'A study of radon emitted from building materials using solid state nuclear track detectors' Journal of Radiation Research and Applied Sciences (8) 516-522

Sudhir Mittal, Asha Rani and Rohit Mehra (2016). 'Estimation of radon concentration in soil and groundwater samples of Northern Rajasthan, India', Journal of Radiation Research and Applied

Sciences, vol 9, pp 125-130.

Tuccimei P, Moroni M, Norcia D (2006) 'Simultaneous Determination of ${ }^{222} \mathrm{Rn}$ and ${ }^{220} \mathrm{Rn}$ Exhalation rates from Building Materials used in Central Italy with Accumulation Chambers and a Continuous Solid State Alpha Detector: Influence of Particle Size, Humidity and Precursors Concentration'. Appl Radiat Isot 64:254 - 263.

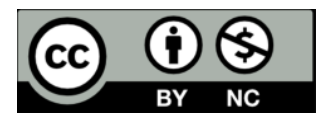

(C)2020 This is an Open Access article distributed under the terms of the Creative Commons Attribution 4.0 International license viewed via https://creativecommons.org/licenses/by/4.0/ which permits unrestricted use, distribution, and reproduction in any medium, provided the original work is cited 